\title{
Withdrawal Notice
}

Title of withdrawn article: Phytochemical Characterization of Natural Dye Extracted from Author(s):

Email:

\section{Senna siamea Pods}

Sonali Hindurao Patil, Dilip Damodar Kurlapkar, Dattaraya Krishna Gaikwad patil.sonali999@gmail.com

Journal:

Open Access Library Journal (OALibJ)

Year: 2020

Volume:

7

Number:

4

Pages (from - to):

$1-11$

DOI (to PDF):

https://doi.org/10.4236/oalib.1106148

1103937

Article page:

http://www.scirp.org/journal/PaperInformation.aspx?PaperID=99425

Withdrawal date:

2020-04-13

Withdrwal initiative (multiple responses allowed; mark with $\mathbf{X}$ ):

$\mathbf{X}$ All authors

$\square$ Some of the authors:

Editor with hints from

O Journal owner (publisher)

O Institution:

O Reader:

O Other:

Date initiative is launched: $2020-04-13$

Withdrawal type (multiple responses allowed):

$\square$ Unreliable findings
O Lab error
Inconsistent data
O Analytical error
O Biased interpretation
O Other:

Irreproducible results

$\square$ Failure to disclose a major competing interest likely to influence interpretations or recommendations

Unethical research

Fraud
O Data fabrication
O Fake publication
O Other:
Plagiarism
Self plagiarism
Overlap
Redundant publication *

Copyright infringement $\square$ Other legal concern:

Editorial reasons

O Handling error

O Unreliable review(s)

O Decision error

O Other:

X Other: Authors requested withdrawal.

Results of publication (only one response allowed):

$\square$ are still valid.

$\mathbf{X}$ were found to be overall invalid.

Author's conduct (only one response allowed):

$\square$ honest error

$\square$ academic misconduct

$\mathbf{X}$ none (not applicable in this case - e.g. in case of editorial reasons)

* Also called duplicate or repetitive publication. Definition: "Publishing or attempting to publish substantially the same work more than once." 


\section{History}

Expression of Concern:

$\square$ yes, date: yyyy-mm-dd

$X$ no

Correction:

$\square$ yes, date: yyyy-mm-dd

$X$ no

\section{Comment:}

The Editorial Board would like to extend its sincere apology for any inconvenience this withdrawal may have caused. 


\title{
Phytochemical Characterization of Natural Dye Extracted from Senna siamea Pods
}

\author{
${ }^{1}$ Department of Botany, Shivaji University, Kolhapur, Maharashtra \\ ${ }^{2}$ S.B. Khade Mahavidyalaya, Koparde, Kolhapur, Maharashtra \\ Email: *patil.sonali999@gmail.com
}

Sonali Hindurao Patil1*, Dilip Damodar Kurlapkar², Dattaraya Krishna Gaikwad1

How to cite this paper: Patil, S.H., Kurlapkar, D.D. and Gaikwad, D.K. (2020) Phytochemical Characterization of Natural Dye Extracted from Senna siamea Pods. Open Access Library Journal, 7: e6148. https://doi.org/10.4236/oalib.1106148

Received: February 7, 2020

Accepted: April 7, 2020

Published: April 10, 2020

Copyright $\odot 2020$ by author(s) and Open Access Library Inc.

This work is licensed under the Creative Commons Attribution International License (CC BY 4.0).

http://creativecommons.org/licenses/by/4.0/

\section{(c) (i) Open Access}

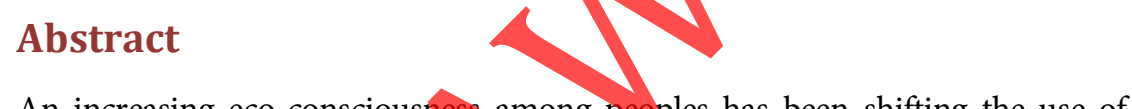

An increasing eco-consciousness among peoples has been shifting the use of natural dyes for textile dyeing and in other realms too as food, pharmaceuticals and cosmetics. The present study was focussed on aqueous extraction of natural dye from the pod husk of Senna siamea (Lam.) H.S. Irwin \& Barneby, its characterization through spectroscopic (UV-VIS and FT-IR) and chromatographic (GC-MS/LC-MS) technique. It was noticed that the percent recovery was $16 \%$, while FTIR results indicates different functional groups present in the dye, total 16 constituents were identified in the GC-MS analysis of Senna dye such as D-Fructose,3-O-methyl-, Stigmast-5-en-3-ol,oleate, Benzaldehyde,2-hydroxy-4methyl-, 3'-Methoxybenzo[1',2'-b]-1,4-, Tetrapentacontane, n-Hexadecanoic acid, 2,3-Dihydroxypropyl elaidate 3-Hydroxy-4-methoxybenzoic acid, 4H-Pyran-4one, 2,3-dihydro-3,5-dihydroxy-6, 4-Hydroxy-2-methylacetophenone, Hexadecanooic acid, 2-hydroxy-1-(hydroxymethyl), Maltol, Methyl 14-methyl-eicosanoate, Bis(2-ethylhexyl) phthalate, 9,12-Octadecadienoic acid (Z,Z)-, 2,3dihydro, Benzeneacetaldehyde, and the LCMS analysis exhibits the presence of 20 major bioactive compounds among these N-Pentadecylcyclohexanecarboxamide, Docosanedioic acid, Emmotin A, $3 \alpha, 12 \alpha$-Dihydroxy-5 $\beta$-chol7-en-24-oic Acid, 4-Hydroxyphenylglyoxylate, Hexadecyl Acetyl Glycerol, 2-oxo-nonadecanoic acid, 1-Monopalmitin, Spisulosine and N,N-dimethylSafingol showed highest retention time. Thus the Senna dye is a rich source of natural bioactive compounds.

\section{Subject Areas}

Plant Science

\section{Keywords}

Natural Dye, UV-VIS, FTIR, GC-MS, LCMS 


\section{Introduction}

Since the dawn of civilization, the art of making natural dye is one of the oldest methods known to humankind [1]. The discovery of synthetic dye was almost replaced the natural dyes. This could have happened because of its own drawbacks like divergence of colour, less availability and lack of fastness properties [2]. Due to toxic and allergic reactions associated with synthetic dyes, ban has been imposed on their uses by Germany and other European countries. Hence there is renaissance in the use of natural dyes in the textile dyeing, for food, pharmaceutical and in cosmetics [3].

Natural dyes obtained from flora and fauna are non-toxic, non-carcinogenic and biodegradable in nature and almost non-pollutant so do not pose serious hazards to environment [4]. The colour range is correlated to chemical structure and chromogen-chromophore correlated with auxo chrome. In textile coloration chromophore and auxo chrome are considered as the most important chemical constituents of dyes [5] [6]. The colour of dyed fabrics depends on the nature of dye constituents [7]. The constituent molecules contain aromatic ring structure coupled with azide chain are usually required for resonance and thus to impart colour. Due to lack of knowledge on the extraction and dyeing of natural dye, it has not been employed Commercially like synthetic dyes [8]. But now a day's considerable research work is started throughout the world on the application of natural dyes [9]. Added to this natural dyes are gaining popularity as UV protective and antimicrobial clothing dyes [10].

Nowadays there has been increasing interest in production of antibacterial textiles because clothing and other textile materials provide essential requirements in the form of moisture and nutrients to pathogenic and odour generating microbes. Natural dyes possess antimicrobial properties because of presence of a considerable amount of antimicrobial compounds such as anthraquinones, flavonoids, tannins, naphthoquinones etc [11]. Natural dye extracted from Punica granatum reported as antibacterial agent as it possesses a considerable amount of tannins. Some other sources of plant dyes such as lawsone from henna, juglone from walnut and lapachol from alkanet are rich in naphthoquinones also exhibit antibacterial properties [12] [13] [14]. There is need to reinvestigate the renewable resources as the alternative raw material as source of natural dyes [15] [16].

Senna siamea (Lam.) H.S.Irwin \& Barneby Formerly, Cassia siamea belongs to family Fabaceae. It is commonly known as kassod tree, cassod tree and cassia tree. In traditional medicine, the fruit is used to prevent convulsion in children. The young fruits and leaves are also eaten as vegetables in Thailand [17]. The plant also possesses antimalarial, antidiabetic [18], antitumor or anticancer [19] [20], laxative [21] anti-inflammatory, analgesic, antipyretic, anxiolytic, antidepressant, and sedative [22] properties. The plants are rich in array of secondary metabolites such as polyphenols, flavonoids, isoflavonoids, phenolic acids, triterpenoids, chromones, anthraquinones, bianthra-quinones, sennosides, steroids, and carotenoids, etc [23], which have been found to possess antimicrobial properties in 
vitro. In the present investigation an attempt has been made to extract the natural water soluble dye from pods of $S$. siamea, to characterize the prepared dye for its chemical constituents and to assess its antibacterial potential.

\section{Material and Methods}

\section{Preparation of Raw Material}

Pods of $S$. siamea were collected from campus of Shivaji University, Kolhapur (Figure 1). The plant material was identified using Flora of Maharashtra state [24] and authenticated by referring to type specimen. A voucher specimen (SHP-001) has been deposited at the Department of Botany, SUK herbarium. The material was washed thoroughly to remove adhering dirt and dried at room temperature. Subsequently, dried material was ground into powder. The powder was passed through a sieve of $25 \mu$ mesh size to obtain uniform particle size of material. The sieved powder was used for dye extraction at different experimental conditions.

\section{Extraction of Dye in Powder Form}

The dye from the pod husk of $S$. siamea was extracted by heating the husk powder and distilled water (M: $\mathrm{C}-10: 100)$ at $80^{\circ} \mathrm{C}-90^{\circ} \mathrm{C}$ for $2 \mathrm{hr}$. The dye solution was filtered and transferred in evaporating dish and dried in oven at $60^{\circ} \mathrm{C}$ then it is cooled and weighed to determine the weight of extract from which the yield (16\%) was calculated. The percentage of the dye powder was calculated from equation 25$]$.
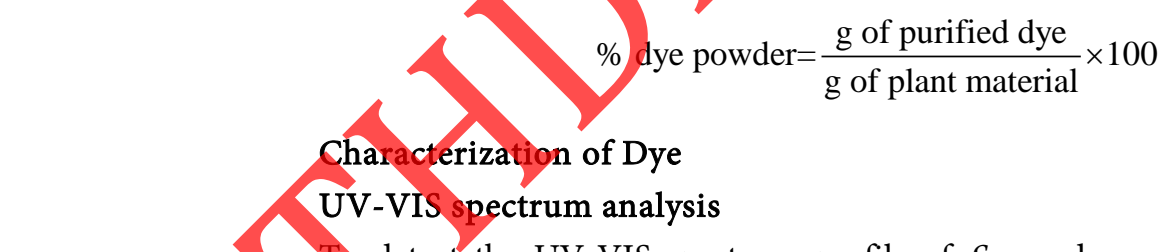

detect the UV-VIS spectrum profile of Senna dye, aqueous extract was scanned in the wavelength ranging from $200-800 \mathrm{~nm}$ using UV-VIS spectrophotometer and the characteristic peak were detected.

\section{FT-IR spectral analysis}

The most characteristics auxo chromic functional group present in S. siamea dye were recorded using FT-IR spectrophotometer (BRUKER ALPHA 100508). The spectrum was located in the range from $500-4000 \mathrm{~cm}^{-1}$ with a resolution of $4 \mathrm{~cm}^{-1}$ and each spectrum composed of 32 scans. Peaks in the spectrum were analysed in accordance with the literature.

\section{GC-MS analysis}

GC-MS analysis of the sample was performed on a SHIMADZU GC-2010.GCMS QP-2010. Column used was Restec Rtx-5MS measuring $60 \mathrm{~mm} \times 0.25 \mathrm{~mm}$ ID thickness of $0.25 \mu \mathrm{m}$ composed of $95 \%$ dimethyl polysiloxane. Helium gas was used as carrier gas at a flow rate of $1 \mathrm{ml} / \mathrm{min}$ and injection volume of $1 \mu \mathrm{l}$ was utilized. During the process the oven temperature was programmed initially at $60^{\circ} \mathrm{C}$ for 5 minutes then an increased to $240^{\circ} \mathrm{C}$ for 5 minutes then programmed to increased up to $280^{\circ} \mathrm{C}$ for 2 minutes at a rate of $10^{\circ} \mathrm{C}$ per minutes ending with 
a 5 minutes. Interpretation of mass spectrum of GCMS was done using database of National Institute standard and Technology (NIST) library. Measurement of peak area and data processing were carried out by Real time analysis software ver.2.6.

\section{LC-MS analysis}

Aqueous extract of Senna dye was subjected to LCMS analysis. An Agilent 6540 UHD QTOF LCMS instrument was used to perform untargeted sample analysis. Zorbax SB-Aq, $3.0 \times 100 \mathrm{~mm} ; 3.5 \mu \mathrm{M}$ column (Agilent 1290 Infinity Binary pump, well plate auto sampler, thermostatted column compartment) with a flow rate of $0.6 \mathrm{ml} / \mathrm{min}$ and $20 \mu \mathrm{l}$ injection volume was used. MS with both positive and negative modes was used (Agilent 6540 UHD QTOF LC/MS/MS). The operating parameters for the LCMS detection were as folfows: nebulizing gas flow 30 psi, drying gas pressure $12 \mathrm{Lmin}^{-1}$ and gas temp. $325^{\circ} \mathrm{C}$, Skimmer voltage $65 \mathrm{v}$, octapole RF $750 \mathrm{v}$, capillary voltage $3.5 \mathrm{kv}$ and fragmented voltage $150 \mathrm{v}$. Data were collected using Mass Hunter Molecular Feature Extrâctor (MFE) tool.

\section{Results and Discussion}

UV-VIS spectral analysis of natural dye was performed for qualitative analysis and for identification of certain classes of compound, main hue, and property of dye. The UV-VIS spectrum of Senna dye extract showed one peak at $287 \mathrm{~nm}$ with the absorption of 1.563. Figure 2 shows absorption spectrum of Senna dye powder.

The comparative data on the peak value with wave numbers and the possible functional groups during FTIR analysis of Senna dye powder are presented in Table 1. FTIR spectrum (Figure 3) exhibit characteristic functional groups are present in Senna dye powder. Peak at $3852.22 \mathrm{~cm}^{-1}, 3739.95 \mathrm{~cm}^{-1}$ and 3225.94 $\mathrm{cm}^{-1}$ was indexed to the $-\mathrm{OH}$ group, at $2927.76 \mathrm{~cm}^{-1}$ assigned to $\mathrm{C}-\mathrm{H}$ stretching in $-\mathrm{CH}_{2}$ group [26]. Presence of $\mathrm{C}-\mathrm{H}$ bond which usually considered as prominent baurd for flavonoid pigment [27]. Peak at $2383.75 \mathrm{~cm}^{-1}$ and $2313.33 \mathrm{~cm}^{-1}$ indicates $\mathrm{O}-\mathrm{H}$ stretching vibration of carboxylic acid [28]. At $1587.22 \mathrm{~cm}^{-1}$ and $1524.80 \mathrm{~cm}^{-1}$ refers to the infrared absorption of $\mathrm{C}=\mathrm{C}$ while $1259.11 \mathrm{~cm}^{-1}$ indicating C-O [29] [30], Peak at $1389.52 \mathrm{~cm}^{-1}$ denotes the ether group, Other peaks at $1057.20 \mathrm{~cm}^{-1}$ and $661.37 \mathrm{~cm}^{-1}$ indicates floroalkane and chloroalkane. The dye had its respective functional group like alcohol, alkane, carboxylic acid, carbonyl, ether, aromatic etc. Hence, the crude extract subjected to UV-VIS and FTIR analysis is used for the identification of chemical constituents present in dye. In addition, UV-VIS and FTIR spectroscopy is proved to be a reliable and sensitive method for detection of bio molecular composition.

The compounds presented in the crude dye powder of $S$. siamea were identified by GC-MS and LCMS analysis. The GC-MS analysis revealed the presence of 16 components presented in Table 2. Figure 4 shows GCMS chromatogram spectrum of Senna dye powder. The identification of phytochemicals was based on the peak area, retention time and compound name. The active compounds along with their respective retention time, area percentage, molecular formula, 
molecular weight are presented in Table 2. The principal constituents were identified in dye extract are D-Fructose, 3-O-methyl-, Stigmast-5-en-3-ol, oleate, Benzaldehyde, 2-hydroxy-4-methyl-, 3'-Methoxybenzo [1', 2'-b]-1, 4-, with percent area of 81.96, 5.41, 3.92 and 3.64 respectively.

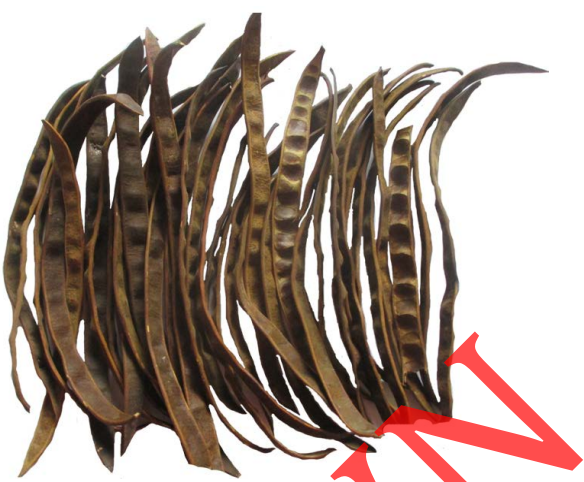

Figure 1. Picture off Senna stamea Pods.

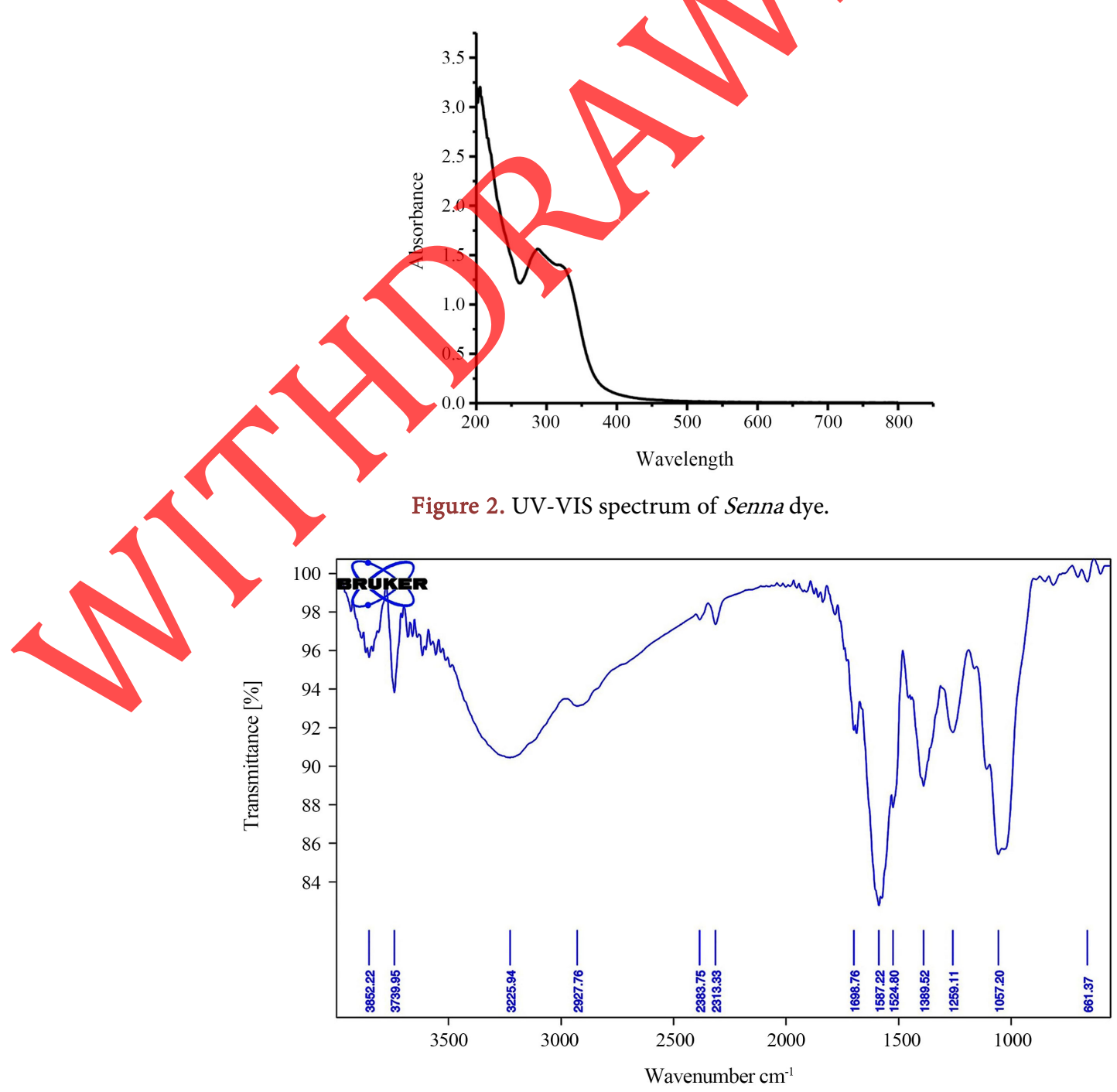

Figure 3. FTIR spectrum of Senna dye. 
Table 1. Functional group analysis of Senna dye using FT-IR spectroscopy.

\begin{tabular}{ccc}
\hline Sr. No. & Wavenumbers $\mathrm{cm}^{-1}$ & Assignments \\
\hline 1 & 3852.22 & \\
2 & 3739.95 & Alcohol (OH) \\
3 & 3225.94 & \\
4 & 2927.76 & Alkane $(\mathrm{C}-\mathrm{H})$ \\
5 & 2383.75 & Carboxylic acid $(\mathrm{O}-\mathrm{H})$ \\
6 & 2313.33 & \\
7 & 1698.76 & Carbonyl $(\mathrm{C}=\mathrm{O})$ \\
8 & 1587.22 & Aromatic $(\mathrm{C}=\mathrm{C})$ \\
9 & 1524.80 & Aromatic $(\mathrm{C}=\mathrm{C})$ \\
10 & 1389.52 & Alkane $(\mathrm{C}-\mathrm{H})$ \\
11 & 1259.11 & Akyl aryl ether $(\mathrm{C}-\mathrm{O})$ \\
12 & 1057.20 & Fluroalkane $(\mathrm{C}-\mathrm{X})$ \\
13 & 661.37 & Chloroalkane $(\mathrm{C}-\mathrm{X})$ \\
\hline
\end{tabular}

Table 2. Bioactive compounds detected in Senna dye extract by GC-MS.

\begin{tabular}{|c|c|c|c|c|c|}
\hline Peak No. & RT & Name of Compound & Molecular Formula & Molecular Weight & Area $\%$ \\
\hline 1 & 18.683 & D-Fructose, 3-O-methyl- & $\mathrm{C}_{7} \mathrm{H}_{14} \mathrm{O}_{6}$ & 194 & 81.96 \\
\hline 2 & 25.241 & Stigmast-5-en-3-ol, oleate & & 678 & 5.41 \\
\hline 3 & 14.036 & Benzaldehyde, 2-hydroxy-4 & $\mathrm{C}_{8} \mathrm{H}_{8} \mathrm{O}_{2}$ & 136 & 3.92 \\
\hline 4 & 25.571 & 3'-Methoxybe & $\mathrm{C}_{11} \mathrm{H}_{14} \mathrm{~N}_{2} \mathrm{O}$ & 190 & 3.64 \\
\hline 5 & 27.623 & Tetronento & $\mathrm{C}_{4} \mathrm{H}_{110}$ & 758 & 0.70 \\
\hline 6 & 19.945 & & $\mathrm{C}_{16} \mathrm{H}_{32} \mathrm{O}_{2}$ & 256 & 0.69 \\
\hline 7 & 30.822 & & $\mathrm{C}_{21} \mathrm{H}_{40} \mathrm{O}_{4}$ & 356 & 0.67 \\
\hline 8 & 15.565 & & $\mathrm{C}_{8} \mathrm{H}_{8} \mathrm{O}_{4}$ & 168 & 0.63 \\
\hline 9 & 9.828 & -3,5-dihydroxy-6 & $\mathrm{C}_{6} \mathrm{H}_{8} \mathrm{O}_{4}$ & 144 & 0.51 \\
\hline 10 & 12.290 & methylacetophenone & $\mathrm{C} 9 \mathrm{H}_{10} \mathrm{O}_{2}$ & 150 & 0.37 \\
\hline 11 & 28.613 & -hydroxy-1-(hydroxymethy) & $\mathrm{C}_{1} 9 \mathrm{H}_{38} \mathrm{O}_{4}$ & 330 & 0.27 \\
\hline 12 & 8.843 & Maltol & $\mathrm{C}_{6} \mathrm{H}_{6} \mathrm{O}_{3}$ & 126 & 0.18 \\
\hline 13 & 19.516 & 14-methyl-eicosanoate & $\mathrm{C}_{22} \mathrm{H}_{44} \mathrm{O}_{2}$ & 340 & 0.16 \\
\hline 14 & 28.842 & Bis (2-ethylhexyl) phthalate & $\mathrm{C}_{24} \mathrm{H}_{38} \mathrm{O}_{4}$ & 390 & 0.15 \\
\hline 15 & 30.757 & tadecadienoic acid (Z,Z)-,2,3-dihydro & $\mathrm{C}_{21} \mathrm{H}_{38} \mathrm{O}_{4}$ & 354 & 0.14 \\
\hline 16 & 8.162 & Benzeneacetaldehyde & $\mathrm{C}_{8} \mathrm{H}_{8} \mathrm{O}$ & 120 & 0.08 \\
\hline
\end{tabular}

The LCMS analysis exhibit 20 different major compounds listed in Table 3, among these Docosanedioic acid used in antiseptics, top-grade coatings, painting materials, corrosion inhibitors, surfactants, and engineering plastics such as nylon 612 [31], $3 \alpha, 12 \alpha$-Dihydroxy-5 $\beta$-chol-7-en-24-oic acid displays cholesterol elevating activity [32]. Hexadecyl Acetyl Glycerol inhibits the growth of HL-60 cells and induces differentiation to cells resembling mononuclear phagocytes [33]. Spisulosine has antiproliferative activity toward advanced malignant solid tumors [34] [35]. Whereas DL-3-Phenyllactic acid is used as natural antibiotic agent. Carnosol is known for its high antioxidative capacities, and have many industrial applications in the fields of foods and beverages, nutrition, and health 
[36]. The compound like 5, 7, 2', 3'-Tetrahydroxyflavone and Nodifloretin displays the antiviral, insecticidal activities [37] [38]. The presence of these compounds (Figure 5) in Senna dye shows a potential source of these bioactive compounds which might be utilized in the development of various pharmaceutical formulations as well as basis of anticancerous and antiviral drugs. Further study of these phytoconstituents may prove the medicinal importance.

Table 3. Bioactive compounds detected in Senna dye extract by LC-MS.

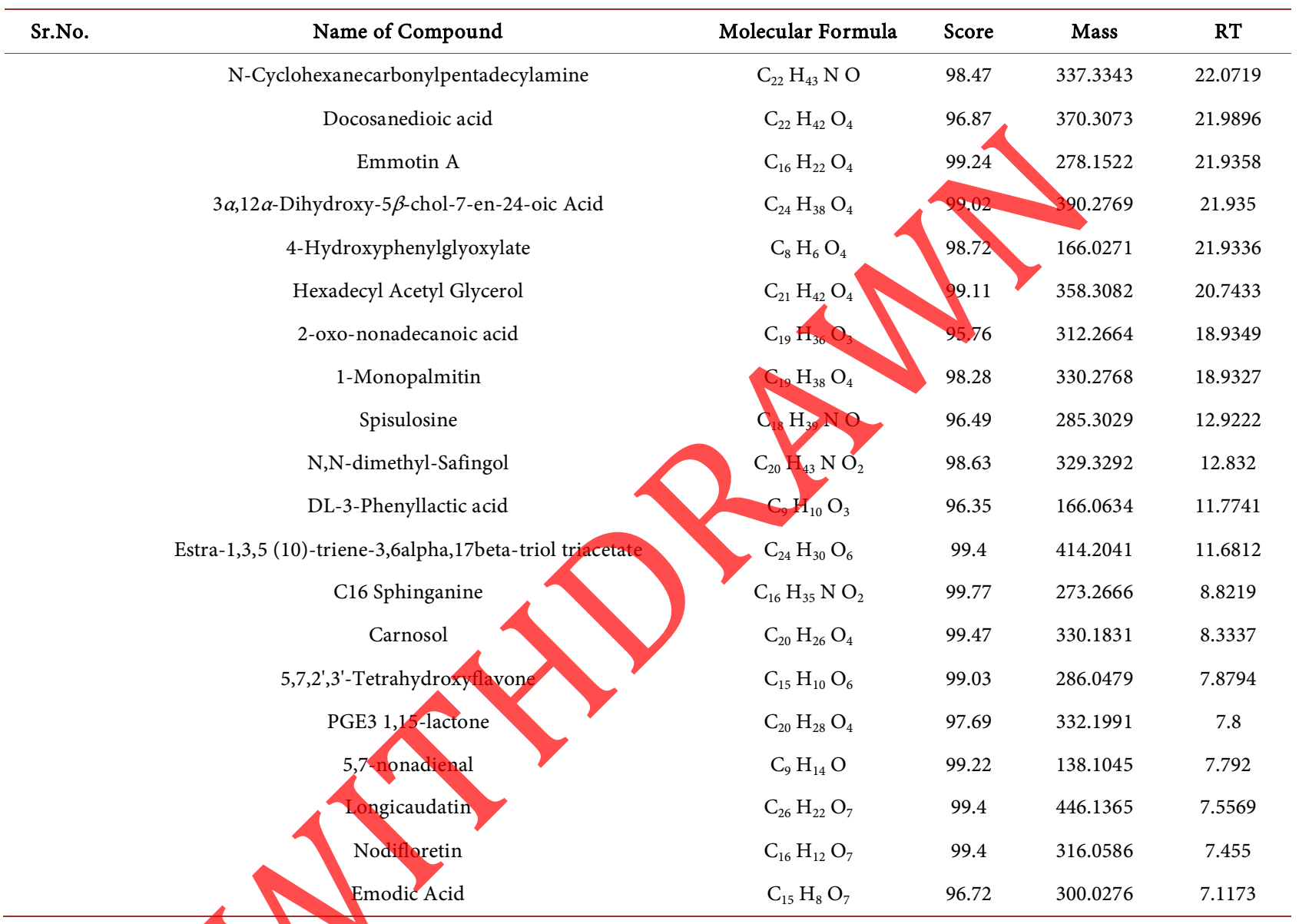

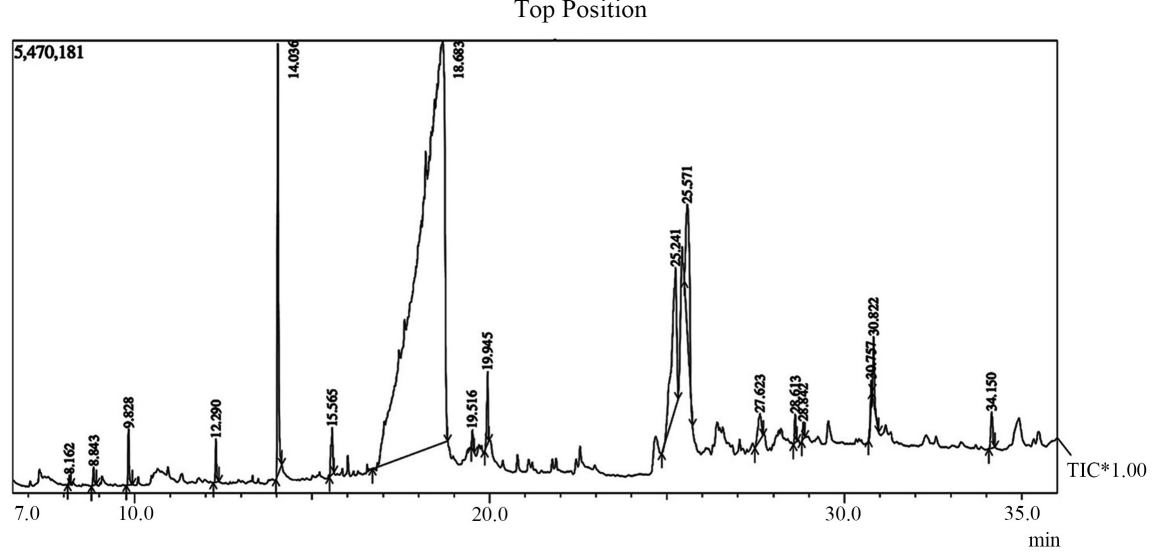

Figure 4. Chromatogram of Senna dye by GC-MS. 


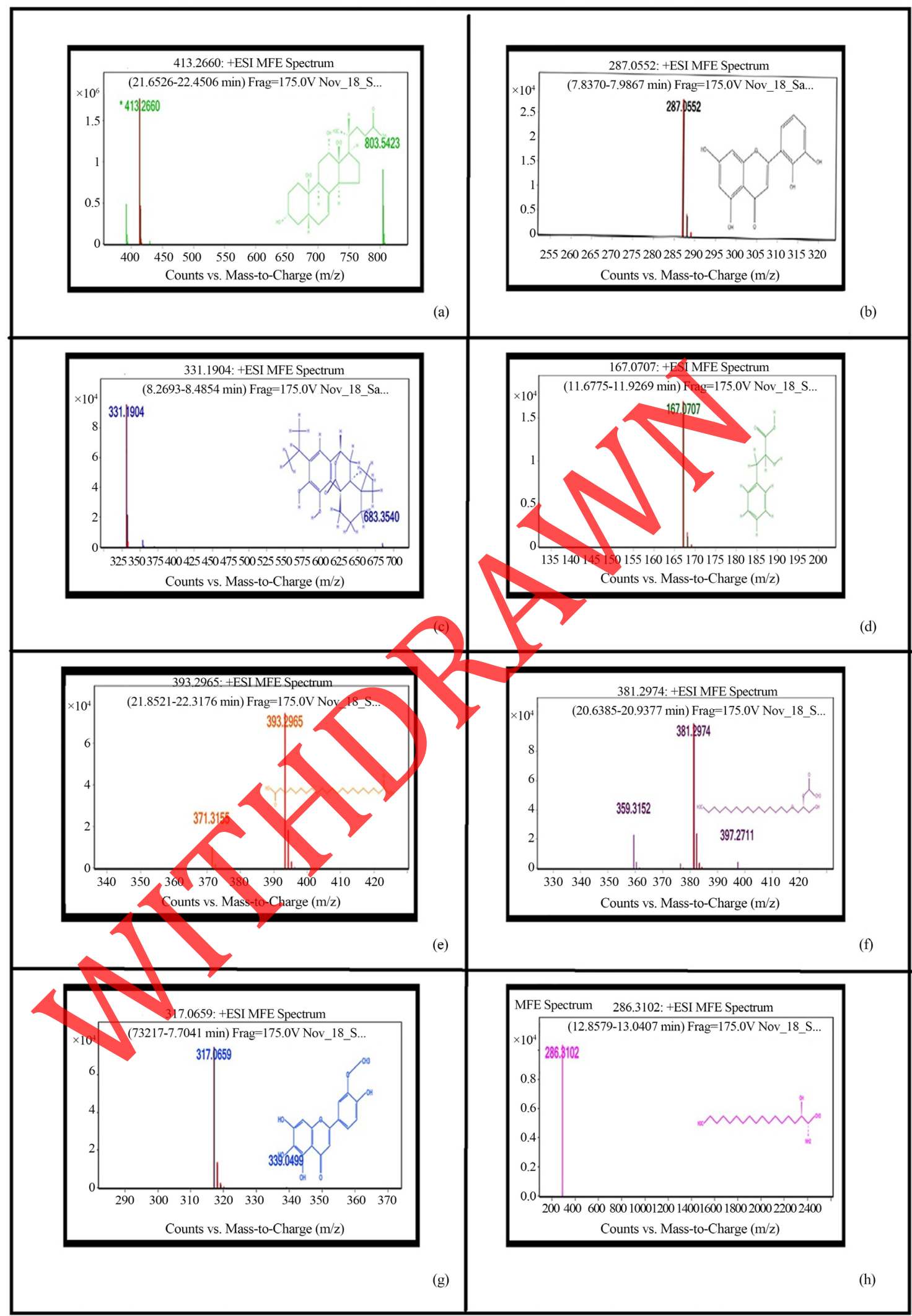

Figure 5. MS spectrum of LCMS compounds: (a) Docosanedioic acid, (b) $3 \alpha, 12 \alpha$-Dihydroxy-5 $\beta$-chol-7-en-24-oic Acid, (c) Hexadecyl Acetyl Glycerol, (d) Spisulosine, (e) DL-3-Phenyllactic acid, (f) Carnosol, (g) 5,7,2',3'Tetrahydroxyflavone, (h) Nodifloretin. 


\section{Conclusion}

The results of GC-MS and LCMS analysis highlighted that the Senna dye is good source of phytochemicals which have a variety of medicinal properties that can be useful for the cure of various diseases. It is clear from the study high bioactive compounds present in dye and also exhibits effective biomedical properties which might be helpful in the development of various drugs as well as pharmaceuticals and bio cosmetic ingredients. The data generated through this work may be used as a basis for studying the economic viability of producing the dyes on a commercial scale.

\section{Acknowledgements}

The authors are grateful to the Department of Botany, Shivaji University, Kolhapur, India for providing necessary facilities, to carry out the present research work.

\section{Conflicts of Interest}

The authors declare no conflicts of interest regarding the publication of this paper.

\section{References}

[1] Kannanmarikani, Kannan, U.S. and Kanniappan, R. (2010) Assessment of Dyeing Properties and Quality Parameters of Natural Dye Extracted from Lawsonia inermis. European Journal of Experimental Biology, 7, 62-70.

[2] Singh, S.V. and Purohit, M.C. (2012) Applications of Eco-Friendly Natural Dye on Wool Fibres Using Combination of Natural and Chemical Mordants. Universal Journal of Environmental Research and Technology, 2, 48-55.

[3] Kumaresan, M., Palanisamy, P.N. and Kumar, P.E. (2012) Application of Eco-Friendly Natural Dye on Cotton Using Combination of Mordants. Indian Journal of Fibre \& Textile, 37, 194-198.

[4] El-Amoudy, E.S. and El-Ebissy, A.A. (2014) Characterization of a New Natural Dye Applied on Wool Fabrics. MSAIJ, 12, 491-504.

[5] Trotman, E.R. (1993) Dyeing and Chemical Technology of Textile Fibres. 6th Edition, Springer, Berlin, 254-286.

[6] Foulds, J. (1995) Dyeing and Printing. A Handbook on Small Scale Textiles. Intermediate Technology Publications, London, 1-27.

[7] Padma, S.V. (2000) Chemistry of Natural Dyes. Facility for Ecological and Analytical Testing (FEAT) at the Indian Institute of Technology, Kanpur, India, Resonance, 73-80. https://doi.org/10.1007/BF02836844

[8] Siva, R. (2007) Status of Natural Dyes and Dye-Yielding Plants in India. Current Science, 7, 916-925.

[9] Acguah, S.B. and Oduru, K.A. (2012) Traditional Cloth Dyeing Enterprise at Ntonso: Challenges and Opportunities. West African Journal of Applied Ecology, 1, 25-36.

[10] Ali, N.F., El-Khatib, E.M. and El-Mohamedy, R.S.S. (2011) Antimicrobial Activity of Wool Fabric Dyed with Natural Dyes. Research Journal of Textile and Apparel, 
15, 1-10. https://doi.org/10.1108/RJTA-15-03-2011-B001

[11] Baliarsingh, S., Panda, A.K., Jena, J., Das, T. and Das, N.B. (2012) Exploring Sustainable Technique on Natural Dye Extraction from Native Plants for Textile: Identification of Colourants, Colourimetric Analysis of Dyed Yarns and Their Antimicrobial Evaluation. Journal of Cleaner Production, 37, 257-264.

https://doi.org/10.1016/j.jclepro.2012.07.022

[12] Gerson, H. (1975) Fungi Toxicity of 1, 4-Napthoquinones to Candida albicans and Trichophyton mentagrophytes. Canadian Journal of Microbiology, 21, 197-205. https://doi.org/10.1139/m75-198

[13] Schuerch, A.R. and Wehrli, W. (1978) b-Lapachone an Inhibitor of Oncorna-Virus Reverse Transcriptase and Eukaryotic DNA Polymerased Inhibitory Effect, Thiol Dependence And Specificity. European Journal of Biochemistry, 84, 197-205. https://doi.org/10.1111/j.1432-1033.1978.tb12157.x

[14] Wagner, H., Kreher, B., Lotter, H., Hamburger, M.O. and Cordell, G.A. (1989) Structure Determination of New Isomeric Naphthol [2, 3,-b] Furan-4, 9-Diones from Tabebuia avellanedae by the Selective INEPT Technique. Helvetica Chimica Acta, 72, 659-667. https://doi.org/10.1002/hlca.19890720406

[15] Gupta, D., Khareb, S.K. and Lahaa, A. (2004) Antimicrobial Properties of Natural Dyes against Gram-Negative Bacteria. Coloration Technology, 120, 167-171. https://doi.org/10.1111/j.1478-4408.2004.tb00224.x

[16] Sarkar, R.K., Purushottam, D. and Chauhan, P.D. (2003) Bacteria-Resist Finish on Cotton Fabrics Using Natural Herbal Extracts. Indian Journal of Fibre \& Textile, 28, 322-331.

[17] Kiepe, P.L. (2001) Effect of Cassia Sianea Hedgerow Barriers on Soil Physical Properties. Geoderma. Journal of Integrative Medicine, 68, 113-720.

[18] Odason, E.E and Kolawole, J. (2007) Anti-Diabetic Properties and Brine Shrimp Toxicity of the Aqueous Extract of the Root of Cassia Siamea Lam. (Ceasalpiniaceae). Nigerian Yournal of Pharmaceutical Research, 6, 66-69.

19] Kupradinun, P., Tepsuwan, A., Tantasi, N., Meesiripun, N., Rungsipipat, A. and Kusamran, W.R. (2011) Anticlastogenic and Anticarcinogenic Potential of Thai Bitter: Gourd Fruits. Asian Pacific Journal of Cancer Prevention, 5, 1299-1305.

[20] Nsonde Ntandou, G.F., Banzouzi, J.T., Mbatchi, B., Elion-Itoua, R.G.D., Etou Ossibi, A.W., Ramos, S., Benoit-Vicale, B., Abena, A.A. and Ouamba, J.M. (2010) Analgesic and Anti-Inflammatory Effects of Cassia siamea Lam. Stem Bark Extracts. Journal of Ethnopharmacology, 127, 108-111. https://doi.org/10.1016/j.jep.2009.09.040

[21] Morales, M.A., Hernández, D., Bustamante, S., Bachiller, I. and Rojas, A. (2009) Is Senna Laxative Use Associated to Cathartic Colon, Genotoxicity, or Carcinogenicity? Journal of Toxicology, 1-8. https://doi.org/10.1155/2009/287247

[22] Wongwitdecha, N. (2007) Neuro-Psychopharma-Cological Studies the Effects of Barakol, a Traditional Thai Medicine. Srinagarind Medical Journal, 22, 325-332.

[23] Eddouks, M., Bidi, A., El Bouhali, B., Hajji, L. and Zeggwagh, N.A. (2014) Antidiabetic Plants Improving Insulin Sensitivity. The Journal of Pharmacy and Pharmacology, 9, 1197-1214. https://doi.org/10.1111/jphp.12243

[24] Singh, N.P., Lakshminarasimhan, P., Karthikeyan, S. and Prasanna, P.V. (2001) Flora of Maharashtra State. Botanical Survey of India, Calcutta.

[25] Muangthai, P., Promrong, N. and Wannawong, C. (2010) Preparation of Purified Dye Powder from the Bark of Livistona speciosa. Science Journal Ubon Ratchathani 
University, 2, 65-70.

[26] Patel, B.H., Desai, K.U. and Jha, P.K. (2014) Azadirachta indica Mediated Bioactive Lyocell Yarn: Chemical and Colour Characterization. In: Advances in Chemistry, Springer, Berlin, 1-8. https://doi.org/10.1155/2014/259171

[27] Aksoz, B.E. and Ertan, R. (2012) Spectral Properties of Chalcone II, FABAD. Journal of Pharmaceutical Sciences, 4, 205-216.

[28] Saravanakumar, K., Adaikala, R. and Umaiyambigai, D. (2016) GC-MS and FT-IR Profiling of Leaves Methanol Extract from the Pleiospermium alatum (Wall. ex Wt. \& Arn) Swingle Rutaceae Family. The Journal of Phytopharmacology, 5, 201-204.

[29] Ramprasath, R., Kavi, G.G. and Rathi, T.S. (2017) Isolation of Natural Dyes from Hibiscus Rosa Sinensis and Marigold Flower and Dyeing Properties of the Dyes on Cotton Cloth. IOSR Journal of Applied Chemistry, 5, 74-79. https://doi.org/10.9790/5736-1005017479

[30] Ludin, N.A., Mahmoud, A.M., Al-Alwani., Mohamad, A.B., Abd Kadhum, A.H., Norul Hamid, N.H., Ibrahim, M.A., Teridi, M.A.M., Tarik, M., Hakeem, A., Mukhlus, A. and Sopian, K. (2018) Utilization of Natural Dyes from Zingiber officinale Leaves and Clitoria ternatea Flowers to Prepare New Photosensitisers for Dye-Sensitised Solar Cells. International Journal of Electrochemistry, 13, 7451-7465. https://doi.org/10.20964/2018.08.04

[31] https://en.wikipedia.org/wiki/Dodecanedioic_acid

[32] https://www.trc-canada.com/produrct-detail/?A727553while

[33] http://www.bertin-20bioreagent.com/pr11529/hexadecyl-acetyl-glycerol

[34] Cuadros, R., Montejo, D, Garcini, E., Wandosell, F., Faircloth, G., Fernández, Sousa, J.M. and Avila, J. (2000) The Marine Compound Spisulosine, and Inhibitor of Cell Proliferation Promotes the Disassembly of Actin Stress Fibers. Cancer Letters, 152, 23-29. https://doi.org/10.1016/S0304-3835(99)00428-0

[35] Faircloth G., Cueyas, C.D. and Marchante, M. (2006) Molluscs: From ChemoEcological Study to Biotechnological Application. In: Potent Anticancer Agents from Marine Molluscs, Volume 43, Springer, Berlin, Germany, 363-379. https://døi.org/10.1007/978-3-540-30880-5_16

[36] Birtic, S., Dussort, P., Pierre, F.X., Bily, A.C. and Roller, M. (2015) Carnosic Acid. Phytochemistry, 115, 9-19. https://doi.org/10.1016/j.phytochem.2014.12.026

Singh, S., Jatav, V.K. and Sharma, S. (2015) Virtual Screening \& Molecular Docking of Glycoprotein b Inhibitor as a Treatment of Herpes Simplex Virus. International Research Journal of Humanities, Engineering \& Pharmaceutical Sciences, 10, 20-24.

[38] Zheng, L. (2008) Application of Lippia nodiflora Extract to Preparing Medicinal Preparation for Treating Hepatitis. China Patent Application CN2007-10084260 20070224. 